\title{
Anestesia para Colecistectomia Videolaparoscópica em Paciente Portador de Doença de Steinert. Relato de Caso e Revisão de Literatura *
}

\section{Anesthesia for Videolaparoscopic Cholecystectomy in a Patient with Steinert Disease. Case Report and Review of the Literature}

\author{
Flora Margarida Barra Bisinotto, TSA ${ }^{1}$, Daniel Capucci Fabri ${ }^{2}$, Maida Silva Calçado ${ }^{3}$, Paula Borela Perfeito ${ }^{4}$, Lucas Vieira \\ Tostes 5; Gabriela Denardi Sousa ${ }^{5}$
}

\begin{abstract}
RESUMO
Bisinotto FMB, Fabri DC, Calçado MS, Perfeito PB, Tostes LV, Sousa GD - Anestesia para Colecistectomia Videolaparoscópica em Paciente Portador de Doença de Steinert. Relato de Caso e Revisão de Literatura.
\end{abstract}

JUSTIFICATIVA E OBJETIVOS: As distrofias miotônicas são doenças neuromusculares de transmissão autossômica dominante. Dentre elas, a distrofia miotônica tipo 1 (DM1), ou doença de Steinert, é a mais comum no adulto e, além do envolvimento muscular, apresenta manifestações sistêmicas importantes. A DM1 representa um desafio para o anestesiologista. Os pacientes apresentam maior sensibilidade às drogas anestésicas e complicações, principalmente cardíacas e pulmonares. Além disso, há a possibilidade de apresentarem hipertermia maligna e crise miotônica. Descreveu-se o caso de um paciente que teve complicação pulmonar importante após ser submetido à anestesia geral.

RELATO DO CASO: Paciente de 39 anos, portador de DM1, foi submetido à anestesia geral para colecistectomia videolaparoscópica. A anestesia foi venosa total com propofol e remifentanil e rocurônio. O procedimento cirúrgico de 90 minutos não apresentou intercorrências, mas após a extubação o paciente apresentou insuficiência respiratória e crise miotônica, que tornou a intubação traqueal impossível. Utilizou-se a máscara laríngea, que possibilitou a oxigenação adequada, e a ventilação mecânica foi mantida até a recuperação total da atividade respiratória. Evolução ocorreu sem outras complicações.

* Recebido (Received from) do CET/SBA do Hospital Escola da Universidade Federal do Triângulo Mineiro (UFTM), Uberaba, MG

1. Professora Adjunta da UFTM; Responsável pelo CET/SBA da UFTM; Doutora em Anestesiologia pela FMB-UNESP

2. ME do CET/SBA do Hospital Escola da UFTM (2006-2008); Médico Assistente do Hospital São Paulo - UNIFESP

3. Anestesiologista do Hospital Escola da UFTM

4. ME do CET/SBA do Hospital Escola da UFTM

5. Graduando do Curso de Medicina da UFTM

Apresentado (Submitted) em 4 de maio de 2009

AAceito (Accepted) para publicação em 24 de dezembro de 2009
CONCLUSÕES: A DM1 é uma doença que apresenta várias peculiaridades para o anestesiologista. O conhecimento minucioso do seu envolvimento sistêmico, associado à ação diferenciada das drogas anestésicas nesses pacientes, proporcionará um ato anestésicocirúrgico mais seguro.

Unitermos: DOENÇAS, Muscular: distrofia miotônica; CIRURGIA, Abdominal: colecistectomia; COMPLICAÇÕES, Pós-Operatórias: insuficiência respiratória

\section{SUMMARY}

Bisinotto FMB, Fabri DC, Calçado MS, Perfeito PB, Tostes LV, Sousa GD - Anesthesia for Videolaparoscopic Cholecystectomy in a Patient with Steinert Disease. Case Report and Review of the Literature.

BACKGROUND AND OBJECTIVES: Myotonic dystrophies are autosomal dominant neuromuscular diseases. Among them, myotonic dystrophy type 1 (MD1), or Steinert disease, is the most common in adults, and besides muscular involvement it also has important systemic manifestations. Myotonic dystrophy type 1 poses a challenge to the anesthesiologist. Those patients are more sensitive to anesthetics and prone to cardiac and pulmonary complications. Besides, the possibility of developing malignant hyperthermia and myotonic episodes is also present.

CASE REPORT: This is a 39-year old patient with DM1 who underwent general anesthesia for videolaparoscopic cholecystectomy. Total intravenous anesthesia with propofol, remifentanil, and rocuronium was the technique chosen. Intercurrences were not observed in the 90-minute surgical procedure, but after extubation, the patient developed respiratory failure and myotonia, which made tracheal intubation impossible. A laryngeal mask was used, allowing adequate oxygenation, and mechanical ventilation was maintained until full recovery of the respiratory function. The patient did not develop further complications.

CONCLUSIONS: Myotonic dystrophy type 1 presents several particularities to the anesthesiologist. Detailed knowledge of its systemic involvement along with the differentiated action of anesthetic drugs in those patients will provide safer anesthetic-surgical procedure.

Keywords: COMPLICATIONS, Postoperative: respiratory failure; DISEASES, Muscular: myotonic dystrophy; SURGERY, abdominal: cholecystectomy.

Endereço para correspondência (Correspondence to):

Dra. Flora Margarida Barra Bisinotto

Praça dos Lírios, 58

Morada das Fontes

38060-460 Uberaba, MG

E-mail: flora@mednet.com.br 


\section{CASE REPORT}

This is a 39 years old male weighing $68 \mathrm{~kg}$, with the diagnosis of MD1 and cholelithiasis, who worked as a salesman, scheduled for videolaparoscopic cholecystectomy, and he was evaluated in the pre-anesthetic outpatient clinic. He had a history of muscular weakness since nine years of age, but only at age 34 when he presented significant dysphagia, gastroesophageal reflux, and cataract the MD was diagnosed. The patient did not have a history of anesthetic procedures, and he used aloe vera. The family history was significant for his mother who died at age of 50 years due to complications of MD and five siblings with the disease (three sisters and two brothers). He had five children, four healthy boys and a girl with MD. On physical exam, he had typical fascies (Figure 1) with lagophthalmos and frontal baldness, difficulty swallowing that affected speech (dysphonia), hypotrophy of the distal muscles of the upper and lower limbs (Figure 2 and 3), myotonia of the hands (difficulty to relax the hands after a contraction), and Mallampati IV. Laboratorial exams were normal except for CK-NAC of

\section{Anesthesia for Videolaparoscopic Cholecystectomy in a Patient with Steinert Disease. Case Report and Review of the Literature}

Flora Margarida Barra Bisinotto, TSA, M.D.; Daniel Capucci Fabri, M.D.; Maida Silva Calçado, M.D.; Paula Borela Perfeito, M.D.; Lucas Vieira Tostes; Gabriela Denardi Sousa

\section{INTRODUCTION}

Myotonic dystrophy (MD), the most common type of muscular dystrophy in adults, is a neuromuscular disorder also known as Steinert disease. It was first described in 1909 simultaneously by Batten and Gibb in England, and Steinert in Germany, who published several cases of patients of the same family with MD1. Muscular dystrophy is caused by an abnormal expansion of the sequence of a trinucleotide (cytosinethymine-guanine) in chromosome 19. It is transmitted genetically (autosomal dominant) and the phenotypical expression is highly variable ${ }^{2}$.

It has an estimated incidence of one in 8,000 births, and the worldwide prevalence ranges from 2.1 to $4.3 / 100,000^{3}$. This disease is characterized by the presence of myotonia, i.e., persistent muscle contraction after voluntary contraction. It is a multisystem disease and it can be associated with severe complications. Anesthesiologists must know the clinical manifestations of this disease to provide appropriate and safe anesthesia for this group of patients when they undergo surgical procedures. The objective of the present report was to present the case of a patient with MD who underwent cholecystectomy under general anesthesia, discussing the anesthetic conduct. We then go on to review the literature on the subject.

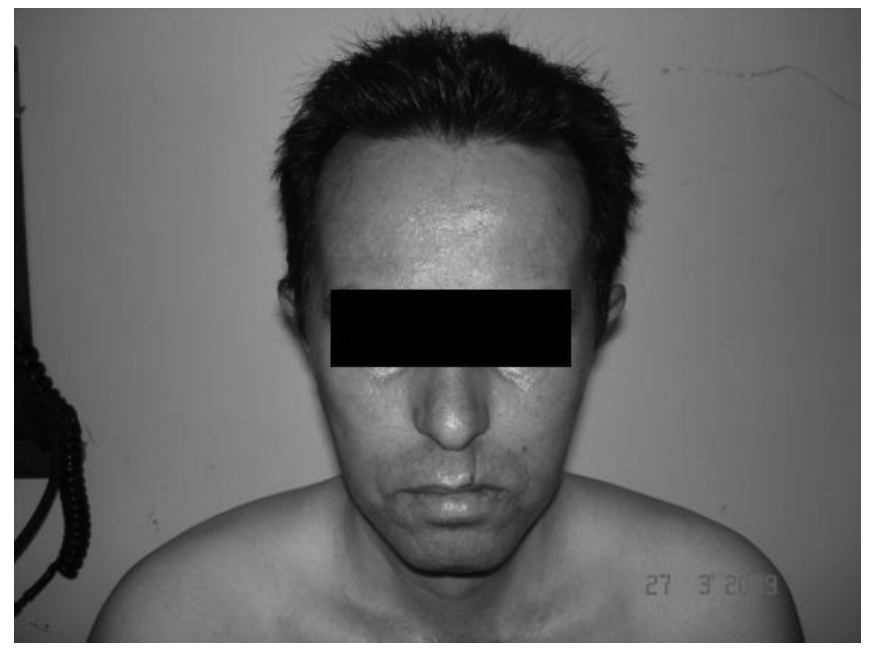

Figure 1 - Facies of a patient with Steinert Disease

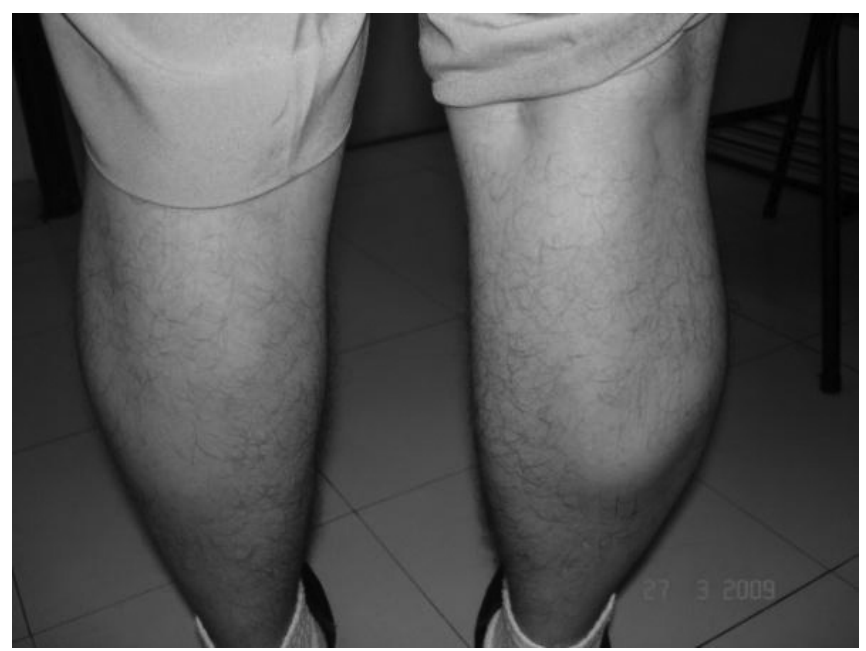

Figure 2 - Lower limb hypotrophy 


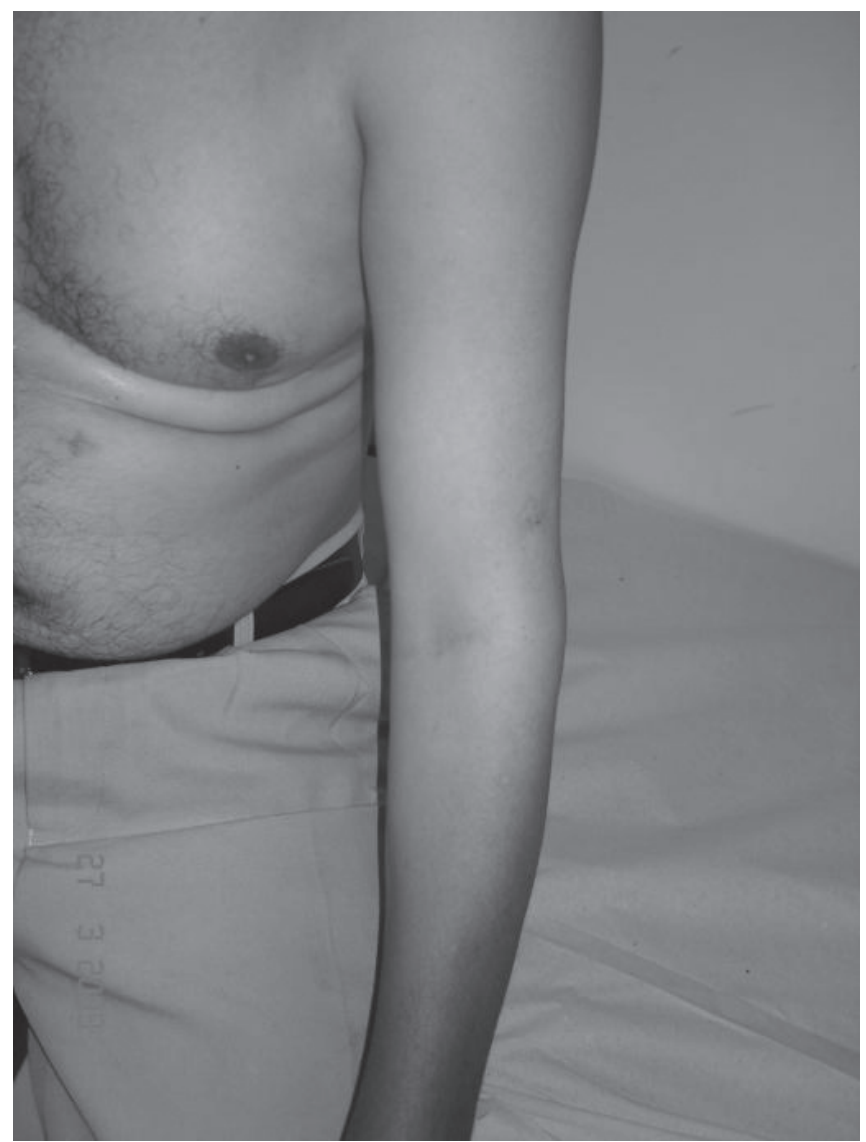

Figure 3 - Upper limb hypotrophy

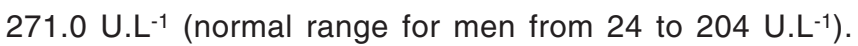
The electrocardiogram showed left branch block, isolated ventricular PVCs, left ventricular overload, and diffuse changes in ventricular repolarization. The chest X-ray and echocardiography were normal. The patient was evaluated by a cardiologist and cleared for the anesthetic-surgical procedure; cardiologic medications were not prescribed. His physical status was classified as ASA 3. The patient received ranitidine $(150 \mathrm{mg})$ and metochlopramide $(10 \mathrm{mg})$ 90 minutes before surgery, but not other pre-anesthetic medication. General anesthesia was induced with midazolam $(5 \mathrm{mg})$, remifentanil $(100 \mu \mathrm{g})$, and rocuronium (50 mg), being intubated with rapid sequence intubation and posterior introduction of an orogastric tube for aspiration. Anesthesia was maintained with $\mathrm{O}_{2}$ and medicinal air at $50 \%$, and continuous infusion of propofol $\left(100 \mu \mathrm{g} \cdot \mathrm{kg}^{-1} \cdot \mathrm{min}^{-1}\right)$ and remifentanil $\left(0.15 \mu \mathrm{g} \cdot \mathrm{kg}^{-1} \cdot \mathrm{min}^{-1}\right)$. Monitoring consisted of pulse oximetry, non-invasive blood pressure, electrocardiogram, capnography, monitoring of muscular relaxation using the train-of-four in the adductor pollicis muscle, and body temperature. The patient underwent videolaparoscopy with insufflation with carbon dioxide to induce pneumoperitoneum, but maintaining the intra-abdominal pressure below $15 \mathrm{mmHg}$. An electrical scalpel was used to facilitate hemostasia. Body temperature was maintained with an electrical blanket. Thirty minutes before the expected end of the surgery, subcutaneous tramadol (100 mg) and intravenous dypirone $(2 \mathrm{~g})$ and ketoprofen $(100 \mathrm{mg})$ were administered. The surgical procedure was completed in 90 minutes, without intercurrences. At that time the patient did not show any response to the train-of-four. We waited for about 20 minutes until the development of at least one response and then the curarization was reversed with atropine $(1.0 \mathrm{mg})$ and prostigmine $(2.0 \mathrm{mg})$. He then showed four equal responses to the train-of-four and responded to verbal commands to open his eyes and mouth. However, his respiratory pattern was not satisfactory. When the patient was regaining consciousness, he reacted to the presence of the ET tube and he was extubated. Pulse oximetry was $98 \%$, but after five minutes he showed progressive decrease in oxygen saturation, without improvement of the respiratory function. His extremities became cold and cyanotic, he developed muscular hypertonia, lost consciousness, and it was difficult to ventilate the patient with the face mask. Tracheal intubation was impossible due to generalized hypertonia. At that time, blood was drawn for ABGs and electrolytes. The laryngeal mask was used, allowing adequate ventilation and oxygenation. Arterial blood gases showed significant cyanosis $\left(\mathrm{pH}=7.17, \mathrm{PaCO}_{2}=77.9\right.$ $\mathrm{mmHg}, \mathrm{PO}_{2}=125.3 \mathrm{mmHg}, \mathrm{HCO}_{3}=28.2 \mathrm{mEq} . \mathrm{I}^{-1}$, and base excess $=-2.3$ ), but the level of electrolytes did not change. Myotonia was diagnosed and treated with midazolam (5 mg) and he remained on controlled ventilation with the laryngeal mask. The patient was transferred to the post-anesthetic recovery room because ICU beds were not available. He regained consciousness slowly and mechanical ventilation continued during this time. After five hours, the laryngeal mask was removed without intercurrences. The patient was transferred to a regular room and discharged from the hospital after three days.

\section{DISCUSSION AND REVIEW OF THE LITERATURE}

Muscular dystrophies belong to a group of hereditary diseases characterized by progressive muscular weakness. There are several classification criteria based on genetic transmission, age of onset of symptoms, muscles involved, and speed of progression.

In the beginning of the 1990s, a mutation in chromosome 19 was identified for the first type of the disease identified genetically and classified as muscular dystrophy type 1 (MD1) or Steinert disease 4 . In 1994, a similar disease was identified, being called proximal myotonic myopathy or muscular dystrophy type 2 (MD2). Nowadays, MD1 refers to the types of the disease related to chromosome 19 and MD2 to new genetically distinct diseases. A repeated sequence of the nitrogenous bases cytosine $(C)$, thymine $(T)$, and guanine $(G)$ of variable length, in which the size of the repeated sequence is correlated with the clinical symptoms of the disease, is the genetic alteration in MD1. It is an autosomal dominant disorder and in the majority of the cases the gene is inherited from the mother, but paternal transmission is seen in a small number 
of cases. Although a neonatal type does exist most patients develop symptoms of MD1 in adult life.

The disease is characterized by muscular involvement and several associated systemic manifestations. Prognosis depends mainly on the cardiac and respiratory repercussions.

Muscular involvement: Myotonia can be seen in several neuromuscular disorders. This word describes a persistent muscle contraction observed after termination of voluntary contraction or stimulation. The patient is not capable of relaxing the muscle after using it. Initially, the muscular involvement manifests as myotonia and atrophy, predominantly in distal portions of the limbs, but it can affect the muscles of the face (facial and temporal muscles) and larynx, and the respiratory muscles. It occurs due to an intrinsic change in the muscle, and not in the peripheral nerve or neuromuscular junction. This can be demonstrated since myotonia is not abolished by peripheral nerve blocks or neuromuscular blockers. Its mechanisms have not been defined. Evidence suggests damage of chloride or sodium channels in the muscular membrane. It has been suggested that complete deactivation of sodium channels and an increase in the activity of calciumdependent potassium channels are contributing factors to increase the excitability and susceptibility to myotonia in $\mathrm{MD}^{5}$. Alternatively, a dramatic reduction in transmembrane chloride conductance can also occur. The primary involvement of peripheral nerves is also controversial, and some authors have suggested that weakness and muscular dystrophy are consequences of a polyneuropathy ${ }^{6}$.

Cardiac involvement: It is represented mainly by deterioration of the conduction system of the heart, tachycardias, cardiomyopathy, and valve diseases ${ }^{7}$. First degree AV block with prolonged PR interval is the most common conduction defect in patients with MD1 and present in the ECG of more than $40 \%$ of the patients. The most common arrhythmia is atrial in origin, but mono or polymorphic ventricular tachycardia can also be seen. Delayed conduction in the His bundle can lead to the development of severe arrhythmias secondary to reentry. Severe rhythm disorders, such as fatal ventricular tachycardia, can develop early in patients with congenital or infantile MD as well as in asymptomatic teenagers with none or little disease manifestation. They can develop sudden cardiac arrest related mainly to physical exertion ${ }^{8}$. Heart failure is present in a significant proportion of patients, but it is not clinically apparent due to the limited physical activity. For this reason, echocardiography is an important exam to quantify the degree of disruption of the cardiac function. Cardiac lesions are progressive and they can evolve for more severe types faster than the evolution of the disease itself, and, in those cases, little correlation between the cardiac and muscular skeletal disease is observed. Therefore, those patients should be followed continuously, paying special attention for cardiovascular manifestations to make the best treatment decisions, and especially for the choice of anesthetic technique and drugs.
Pulmonary involvement: Pulmonary complications are multifactorial and frequent causes of morbimortality in MD. Patients show weakness of the respiratory muscles, and altered central control of the respiration with changes in respiratory mechanisms, leading to global hypoventilation, microatelectasis, and reduction in pulmonary compliance. Ventilatory response to carbon dioxide is reduced, which might have a central origin or be attributed to a reduction in the contractile strength of the diaphragm ${ }^{9}$. This function is further diminished in upper abdominal surgeries. Several studies have suggested that central control mechanisms of respiration are normal in patients with $\mathrm{MD}^{9,10}$. Chronic hypercapnia is a common finding and can be seen even in the presence of minimal signs of peripheral muscular weakness. Along with hypoventilation, patients have day time somnolence, which is also not related to the symptoms of muscular weakness, but it can be due to changes in the respiratory center or sleep disorders characterized mainly by the presence of central or obstructive sleep apnea. Muscular weakness can affect the diaphragm and other respiratory muscles causing difficulty to cough and reduction in functional residual capacity. Weakness of the abdominal muscles that despite showing increased work during respiration is not effective in improving respiratory parameters also contributes for the respiratory complications. Increased sensitivity to sedative and anesthetic drugs can be seen.

Gastrointestinal manifestations: Gastrointestinal manifestations are present in $80 \%$ of the cases, being considered important for the quality of life of MD patients. The most common symptoms include: nausea, vomiting, dysphagia, early satiety (due to a reduction in gastric emptying time), and gastroesophageal reflux ${ }^{11}$. Both myopathic weakness and myotonia of the oropharyngeal muscles are highly important in the dysfunction during the oral and pharyngeal phases of swallowing in patients with $\mathrm{MD}^{12}$. Cholelithiasis is a common finding due to the increase in vesicular biliary sphincter. For unknown reasons, liver function tests are abnormal ${ }^{13}$.

Endocrine involvement: It can include hypothyroidism, hypogonadism, altered secretion of the growth hormone, and abnormalities in glucose metabolism and insulin (frequently associated with diabetes mellitus) ${ }^{10}$. Asymptomatic female patients can also develop infertility.

Central nervous system: Regarding the personality, changes in behavior were observed in the first descriptions, but until the 1980s very few cases were reported, which are usually related to the severity of the muscular involvement. Obsessive-compulsive and passive-aggressive behaviors, as well as apathy and depression, are common in patients with MD. Mental retardation can be seen in $60 \%$ of the congenital types of $\mathrm{MD}$, affecting severely all measures of general intelligence. Classical types of the disease, juvenile and adult, develop cognitive decline, characterizing dementia. Personality, motivation, and emotional changes can lead to social isolation ${ }^{14-16}$. 


\section{Anesthesia Planning and Perioperative Factors Associ- ated with the Development of Myotonia}

Several precautions should be taken not only during anesthesia, but also in the postoperative period in patients with Steinert disease to prevent known complications. The development of myotonia represents an important problem for anesthesia because, if laryngeal and respiratory muscles are involved, intubation can be difficult or even impossible ${ }^{17}$. Potential trigger factors include the surgery, hypothermia, tremors, electrical or mechanical stimulation during or after the surgery, drugs (clofibrate, propranolol, potassium), and anesthetic agents, such as succinylcholine, and anticholinesterase drugs ${ }^{18}$. Treatment is mainly preventive, avoiding all triggering factors. A protocol of safe anesthetics should be adopted. The use of electrical scalpel should be avoided. Body temperature should be monitored closely to minimize the risk of tremors.

The anesthetic technique of choice remains uncertain. Whenever possible, peripheral nerve block or neuroaxis block is the technique of choice ${ }^{19}$. When general anesthesia is indicated, extreme care should be taken during all phases of anesthesia. During anesthetic induction, thiopental is relatively contraindicated due to more prolonged respiratory depression. Propofol has been used both for induction and maintenance of anesthesia, but it can also be a problem. Changes in sensitivity, which may be increased or decreased, in patients with MD have been reported in the literature, and, consequently, it can be difficult to calculate the proper dose $e^{20,21}$.

Although a direct relationship between MD and malignant hyperthermia has not been reported in the literature, depolarizing neuromuscular blockers represent a particular problem, since they can have unpredictable effects ${ }^{22}$. Succinylcholine seems to have a double effect in myotonic patients. It can cause a "normal" neuromuscular blockade, but it can affect the muscles directly causing muscular contraction and enough hyperkalemia to lead to cardiac arrest. Besides, it can initiate a generalized myotonic response, resulting in difficulty in tracheal intubation and ventilation ${ }^{23}$. Therefore, the use of succinylcholine in patients with myotonic dystrophy should be avoided, although some cases of administration of this drug in emergency situations in patients with MD without complications have been reported in the literature ${ }^{24}$. Since myotonia is caused by a primary defect in the musculature, the use of non-depolarizing agents does not abolish generalized contraction.

Non-depolarizing neuromuscular blockers have an unpredictably long action in patients with MD, and the cases reported in the literature suggest a reduction in the dose and use of drugs with intermediate duration, especially atracurium ${ }^{22,25}$. Nish et al. ${ }^{26}$ calculated the effective dose for $50 \%$ and $90 \%\left(E_{50}\right.$ and $E D_{90}$ respectively) of the patients to achieve neuromuscular blockade of vecuronium for the orbicularis, adductor pollicis, and flexor hallucis muscles in a patient with MD undergoing general anesthesia with a laryngeal mask and maintenance with propofol, nitrous oxide, and fentanyl. The $\mathrm{ED}_{50}$ for the orbicularis, adductor pollicis, and flexor hallucis muscles was 7.77 (3.10-16.8), 28.3 (20.7-43.3), and 29.5 (11.0-85.6) $\mu \mathrm{g} . \mathrm{kg}^{-1}$, respectively $(\mathrm{p}<0.01)$, and $\mathrm{ED}_{90}$ of $35.7(14.8-66.5)$,
51.8 (29.3-145.0), and 50.6 (5.29-642.0) $\mu \mathrm{g} . \mathrm{kg}^{-1}$, respectively $(p<0.01)$, indicating a marked increase in susceptibility only for the orbicularis muscle. Other authors ${ }^{27}$ had already shown an increase in muscular sensitivity to vecuronium, especially of the face muscles. Those drugs do not change the muscular tension triggered by the hyperexcitability of the muscular membrane in myotonia and metabolic exhaustion in malignant hyperthermia. It is not known whether the administration of anticholinesterase agents induces myotonia, although the unpredictability of its action has been reported ${ }^{28}$. Those patients also show increased sensitivity to opioids and their dose should be decreased 29 .

As for halogenated anesthetics, it has been questioned whether all myopathies are associated with an increased risk of malignant hyperthermia (MH). In 2004, it was recognized that approximately $50 \%$ of the patients identified as being susceptible to malignant hyperthermia by the contracture test had mutations of the ryanodine receptor, which is responsible for the development of this complication ${ }^{30}$. Several studies have shown that $30-50 \%$ of the individuals susceptible to $\mathrm{MH}$ have myopathological changes ${ }^{31}$.

Takhar et al. ${ }^{18}$ reported a case of videolaparoscopic cholecystectomy using alfentanil, propofol and sevoflurane, and nitrous oxide without neuromuscular blockers, resulting in elevated abdominal insufflation pressures around $20 \mathrm{mmHg}$. Complications related with the anesthetic technique were not observed. The use of general anesthesia has been reported with diazepam, propofol, rocuronium, isoflurane, and morphine ${ }^{32}$. Due to the doubts, it is prudent to avoid drugs that could potentially trigger malignant hyperthermia in patients with myotonic dystrophy ${ }^{33}$.

Large size surgeries in patients with Steinert disease have also been reported in the literature. Gelsomino et al. ${ }^{34}$ reported a series of six patients with myotonic dystrophy who underwent cardiac surgery with hypothermic extracorporeal circulation. Anesthesia was maintained with midazolam, remifentanil, propofol, and atracurium. Complications were not reported. Propofol, sufentanil, atracurium, and clonidine were used successfully in another patient undergoing cardiac surgery ${ }^{35}$.

In a study ${ }^{36}$ with 219 patients with MD undergoing anesthesia, the authors reported a rate of complication of $8.2 \%$, mostly pulmonary and mainly in upper abdominal surgeries. Besides, the severity of the disease and age above 37 years also contributed to increase the incidence of respiratory complications. The risk of pulmonary complications was 14 times higher in patients with proximal muscular weakness when compared with those with less severe disease. Weakness of the pharyngeal musculature can lead to obstructive apnea and aspiration pneumonia. Weakness of the respiratory muscles can prevent effective coughing, leading to the formation of atelectasis. The inspiratory effort decreases inspiratory capacity and increases the risk of alveolar hypoventilation. Most complications in patients with MD are pulmonary in origin. Acute respiratory failure causing retention of carbon dioxide such as in the case presented here is a common complication in those patients. The majority of anesthetic drugs including 
halogenated, hypnotic, and opioid drugs as well as neuromuscular blockers can induce hypoventilation and respiratory failure. Thus, ventilatory assistance is extremely important in the immediate postoperative period. Mechanical ventilation with tracheal intubation has been used for ventilatory support, although it can increase the risk of pulmonary infection, even for short periods. Besides, sedation is required to prevent the discomfort of the tracheal tube. This can prolong the recovery time of the respiratory function. The laryngeal mask minimized the need for sedation, since it is less traumatic for the airways and cardiovascular system. It is better tolerated by the patient, allowing calmer arousal, attenuating airways and hemodynamic reflexes. Potential complications of the laryngeal mask, such as hypopharyngeal trauma and aspiration, have been reported ${ }^{37,38}$. We considered the possibility of aspiration of gastric contents during surgery, and maintaining the torso of the patient elevated in the recovery room was responsible for making the procedure safer regarding the risks of aspiration, since complications were not observed in the late postoperative period. Other ventilation modalities, such as positive pressure in the airways (BIPAP) with face mask, have been effective in improving oxygenation and reducing hypercapnia ${ }^{39}$. Postoperative BIPAP has also been reported in conjunction with the laryngeal mask ${ }^{40}$.

In view of what happened during anesthesia of this patient with MD, we conclude that deep knowledge of the disease, which is multisystemic and demands careful anesthetic planning by anticipating complications, is recommended.

\section{REFERÊNCIAS - REFERENCES}

01. Tramonte JJ, Burns TM - Myotonic dystrophy. Arch Neurol, 2005;62:1316-19.

02. Day JW, Ranum LPW - Genetics and molecular pathogenesis of the myotonic dystrophies. Curr Neurol Neurosci Rep, 2005;5:55-59.

03. Mahadevan M, Tsilfidis C, Sabourin L et al. - Myotonic dystrophy mutation: an unstable CTG repeat in the 3' untranslated region of the gene. Science, 1992;255:1253-1255.

04. Kornblum C, Lutterbey G, Bogdanow M et al. - Distinct neuromuscular phenothypes in myotonic dystrophy types 1 e 2: a whole body highfield MRI study. J Neurol, 2006;253:753-761.

05. Luek JD, Mankodi A, Swanson MS et al. - Muscle chloride channel dysfunction in two mouse models of myotonic dystrophy. J Gen Physiol, 2007;129:79-94.

06. anaite PA, Gantelet E, Kraftsik R et al. - Myotonic dystrophy transgenic mice exhibit pathologic abnormalities in diaphragm neuromuscular junctions and phrenic nerves. J Neuropathol Exp Neurol, 2008;67:763772.

07. Sovari AA, Bodine CK, Farokhi F - Cardiovascular manifestations of myotonic dystrophy-1. Cardiol Rev, 2007;15:191-194.

08. Bassez G, Lazarus A, Desguerre I et al. - Severe cardiac arrhythmias in young patients with myotonic dystrophy type 1. Neurology, 2004;63:1939-1941.

09. Ugalde V, Walsh S, Abresch RT et al. - Respiratory abdominal muscle recruitment and chest wall motion in myotonic muscular dystrophy. J Appl Physiol, 2001;91:395-407.

10. Begin $\mathrm{P}$, Mathieu J, Almirrall J et al. - Relationship between chronic hypercapnia and inspiratory -muscle weakness in myotonic dystrophy. Am J Respir Crit Care Med, 1997;156:133-139.
11. Ronnblom A, Andersson S, Hellstrom PM et al. - Gastric emptying in myotonic dystrophy. Eur J Clin Invest, 2002;32:570-574.

12. Ertekin C, Yüceyar N, Aydogdu Ï et al. - Electrophysiological evaluation of oropharyngeal swallowing in myotonic dystrophy. J Neurol Neurosurg Psychiatry, 2001;70:363-371.

13. Heatwole CR, Miller J, Martens B et al. - Laboratory abnormalities in ambulatory patients with myotonic dystrophy type 1. Arch Neurol, 2006;63:1149-1153.

14. Modoni A, Silvestri G, Pomponi MG et al. - Characterization of the pattern of cognitive impairment in myotonic dystrophy type 1. Arch Neurol, 2004;61:1943-1947.

15. Antonini G, Soscia F, Giubilei $F$ et al. - Health-related quality of life in myotonic dystrophy type 1 and its relationship with cognitive and emotional functioning. J Rehabil Med, 2006;38:181-185.

16. Schulz PE, Mclntosh AD, Kasten MR et al. - A role for myotonic dystrophy protein kinase in synaptic plasticity. J Neurophysiol, 2003;89:1177-1186.

17. Mahr A, Attof $Y$, Flamens $C$. et al. - Prise en charge anesthésique des patients porteurs de myotonie de Steinert: à propos de deux cas cliniques. Ann Fr Anesth Reanim, 2009;28:161-164.

18. Takhar AS, Thaper A, Byrne A et al. - Laparoscopic cholecystectomy in a patient with myotonic dystrophy. J R Soc Med, 2004;97:284-5.

19. Araújo FS, Bessa Jr RC, Castro $\mathrm{CH}$ et al. - Anestesia no paciente com doença de Steinert. Relato de caso. Rev Bras Anestesiol, 2006;56:649-653.

20. Speedy $\mathrm{H}$ - Exaggerated physiological response to propofol in myotonic dystrophy. Br J Anaesth, 1990;64:110-112.

21. Morimoto $\mathrm{Y}, \mathrm{Mii} \mathrm{M}$, Hirata $\mathrm{T}$ et al. - Target-controlled infusion of propofol for a patient with myotonic dystrophy. J Anesth, 2005; 19:336-338.

22. Parness J, Bandschapp O, Girard T - The myotonias and susceptibility to malignant hyperthermia. Anesth Analg, 2009;109:1054-1064.

23. Larach MG, Rosenberg H, Gronert GA et al. - Hyperkalemic cardiac arrest during anesthesia in infants and children with occult myopathies. Clin Pediatr (Phila), 1997;36:9-16.

24. Tomlison S, Macartney I, Lam S - Dystrophica myotonia and suxamethonium. Anaesthesia, 1999;54:1234.

25. Nightingale $P$, Healy TEJ, McGuinness $K$ - Dystrophia myotonica and atracurium. A case report. Br J Anaesth,1985;57:1131-5.

26. Nishi $\mathrm{M}$, Itoh $\mathrm{H}$, Tsubokawa $\mathrm{T}$ et al. - Effective doses of vecuronium in a patient with myotonic dystrophy Anaesthesia, 2004;59:1216-1218.

27. Diefenbach C, Lynch J, Abel M et al. - Vecuronium for muscle relaxation in patients with dystrophia myotonica. Anesth Analg, 1993;76:872874.

28. Buzello W, Krieg N, Schlickewei A - Hazards of neostgmine in patients with neuromuscular disorders. Report of two cases. Br J Anaesth, 1982;54:529-534.

29. Grimsehl K, Wilson E - Remifentanil in myotonic dystrophy - avoiding the use of muscle relaxants and long acting opioids. Internet $\mathrm{J}$ Anesthesiol, 2000;4(1). Disponível em: <http://www.ispub.com/journal/the_internet_journal_of_anesthesiology>.

30. Sei Y, Sambuughin N, Muldoon S - Malignant hyperthermia genetic testing in North America, Working Group Meeting. Bethesda, Maryland, September 4-5, 2002. Anesthesiology, 2004;100:464-465.

31. Payen JF, Bosson JL, Brambilla E et al. - Histological support for the difference between malignant hyperthermia susceptible (MHS), equivocal (MHE) and negative (MHN) muscle biopsies. $\mathrm{Br} \mathrm{J}$ Anaesth, 1997;79:327-331.

32. Ioscovich A, Barth D, Briskin A - Biphasic intermittent positive airway pressure (BIPAP) ventilation support in the postoperative period for patients with myotonic dystrophy. Internet J Anesthesiol, 2006;10(2). Disponível em: <http://www.ispub.com/journal/the_internet_journal_ of_anesthesiology>.

33. Wappler F-Malignant hyperthermia. Eur J Anaesthesiol, 2001;18:632652.

34. Gelsomino S, Lorusso R, Billè G et al. - Cardiac surgery in type-1-myotonic muscular dystrophy (Steinert syndrome) associated to Barlow disease. Interactive Cardiovasc Thorac Surg, 2008;7:222-6. 
35. Klompe L, Lancé $M$, van der Woerd $D$ et al. - Anaesthesiological and ventilatory precautions during cardiac surgery in Steinert's disease. J Card Surg, 2007;22:74-75.

36. Mathieu J, Allard P, Gobeil G et al. - Anesthetic and surgical complications in 219 cases of myotonic dystrophy. Neurology, 1997;49:16491650.

37. McCrory CR, McShane AJ - Gastroesophageal reflux during spontaneous respiration with the laryngeal mask airway. Can J Anaesth, 1999;46:268-270.

38. White RJ, Bass S - Anaesthetic management of a patient with myotonic dystrophy. Paediatr Anaesth, 2001;11:494-497.

39. Aguilo R, Togores B, Pons S et al. - Noninvasive ventilatory support after lung resectional surgery. Chest, 1997;112:117-121.

40. Groudine SB, Lumb PD, Sandison MR - Pressure support ventilation with the laryngeal mask airway: a method to manage severe reactive airway disease postoperatively. Can J Anaesth, 1995;42:341-343.

\section{RESUMEN}

Bisinotto FMB, Fabri DC, Calçado MS, Perfeito PB, Tostes LV, Sousa GD - Anestesia para Colecistectomía Videolaparoscópica en Paciente Portador de Enfermedad de Steinert. Relato de Caso y Revisión de la Literatura.

JUSTIFICATIVA Y OBJETIVOS: Las distrofias miotónicas son enfermedades neuromusculares de transmisión autosómica dominante. Entre ellas está la distrofia miotónica tipo 1 (DM1), o enfermedad de
Steinert, que es la más común en el adulto y además de la involucración muscular, presenta manifestaciones sistémicas importantes. La DM1 representa un reto para el anestesiólogo. Los pacientes presentan una mayor sensibilidad a los fármacos anestésicos y complicaciones, principalmente cardíacas y pulmonares. Además de eso, existe la posibilidad de presentar hipertermia maligna y crisis miotónica. Se ha descrito el caso de un paciente que tuvo una complicación pulmonar importante después de haber sido sometido a la anestesia general.

RELATO DEL CASO: Paciente de 39 años, portador de DM1, sometido a la anestesia general para colecistectomía videolaparoscópica. La anestesia fue venosa total con propofol y remifentanil y rocuronio. El procedimiento quirúrgico de 90 minutos no presentó intercurrencias, pero después de la extubación, el paciente presentó insuficiencia respiratoria y crisis miotónica, que hizo la intubación traqueal imposible. Se utilizó la máscara laríngea, que posibilitó la oxigenación adecuada, y la ventilación mecánica se mantuvo hasta la recuperación total de la actividad respiratoria. Evolucionó sin otras complicaciones.

CONCLUSIONES: La DM1 es una enfermedad que presenta varias peculiaridades para el anestesiólogo. El conocimiento minucioso de su involucración sistémica, asociado a la acción diferenciada de los fármacos anestésicos en esos pacientes, proporcionará un acto anestésico-quirúrgico más seguro. 